\title{
Effect of certain plant oils on some biological and biochemical aspects on the
} cotton leaf worm Spodoptera littoralis.

\author{
Hanan, S. Abdel-Aziz ${ }^{1}$; Hanan, H. Osman ${ }^{1}$; Samya, Z. Sayed ${ }^{1}$ and \\ El-Gohary, E. E. El-Gohary ${ }^{2}$ \\ 1-Plant Protection Res. Inst., ARC, Dokki, Giza, Egypt. \\ 2-Entomology Department, Faculty of Science Ain Shams University, Cairo, Egypt.
}

\section{ABSTRACT}

The latent effects of three plant oils; namely thyme , bitter and neem on certain biological and biochemical parameters of the $6^{\text {th }}$ instar larvae of Spodoptera littoralis treated as $2^{\text {nd }}$ and $4^{\text {th }}$ instars with the $\mathrm{LC}_{50}$ values of these oils. The results showed that the $2^{\text {nd }}$ instars were more susceptible to all the tested oils than the $4^{\text {th }}$ instar larvae. All treatments recorded significantly difference in all durations for both $2^{\text {nd }}$ and $4^{\text {th }}$ instars. Also, highly significant prolongation in pupal duration and the most prolonged oil was occurred by thyme on the $2^{\text {nd }}$ instars, while bitter was more effective on the $4^{\text {th }}$ instar larvae. Longevity of both sexes was reduced specially for male moths. No significant reduction was noticed on female longevity as a result of pretreated $2^{\text {nd }}$ but significant reduction was recorded for pretreated $4^{\text {th }}$ instars especially with thyme. Highly significant reduction in pupal weight produced from the treated $2^{\text {nd }}$ and $4^{\text {th }}$ larval instars with the three products. All oils caused deformations with various degrees for larvae, pupae and adults resulted from the treated $2^{\text {nd }}$ and $4^{\text {th }}$ instar larvae. The highest deformations exist in larval-pupa intermediate by thyme as pretreated $2^{\text {nd }}$ and $4^{\text {th }}$ of the larval instars. Bitter gave the highest pupal deformation as the pretreated $4^{\text {th }}$ instars followed by neem for the $2^{\text {nd }}$ and $4^{\text {th }}$ instars. Generally, all oils exhibited higher effect on the males. Total malformation during all generation recorded its maximum value with neem treatment as $2^{\text {nd }}$ instars then thyme was the most effective in both $4^{\text {th }}$ and $2^{\text {nd }}$ of the larval instars followed by bitter. Highly significant stimulation in chitinase and $\alpha-\& \beta$-esterases activity was recorded with all treatments and the most effective one caused by thyme followed by bitter. Highly significant inhibition in protease activity and acetylcholine esterase (AChE) was attained by (bitter \& thyme) and (neem \& thyme) oils, respectively. While high significant stimulation was recorded in protease and non significant stimulation of AChE was noticed by neem and bitter, respectively.

Keywords: S. littoralis, plant oils thyme, bitter and neem, chitinase, protease, $\alpha$ - esterase, $\beta$-esterase, AchE.

\section{INTRODUCTION}

The cotton leaf worm, Spodoptera littoralis (Boised) is swarming polyphagous, foliage feeding insect that is distributed throughout the world. The insect is one of the major cotton pests that has at least 7 generations during the cotton season as well as infesting more than 120 other crops and vegetables of economic importance (Khawas and Abd El-Gawad, 2002). In Egypt, insecticidal activity of natural plant extracts may play an increasingly prominent role as alternatives to synthetic pesticides due to the increasing concern on health hazards, environmental pollution and negative effects on non target organisms. Few botanicals such as neem oil and some essential oils which characterized by a strong odour and formed by aromatic plants as secondary 
metabolites can used as biological control agents (Bakkali et al., 2008). Thyme (Thymus vulgaris L.) which grows in several regions in the world and is used by the Greeks and Romans in cooking as a source of honey. Lectin was extracted from seeds of Citrullus colocynthis and act as $\alpha$-amylase inhibitors, lectin-like (Ramzi and Sahragard 2013), Botanical pesticides may control the pest population through a different action activity acting primarily as an oral poison, acute toxicity, feeding deterrent, repellent, growth regulator or inhibition of reproduction. The mechanisms of toxicity of essential oils have not been fully identified and display symptoms similar to toxins with a neurotoxic mode of action. They are very effective against more than 200 species of insect-pests some of whom are resistant to chemical pesticides or are otherwise difficult to control.

The aim of the present investigation is to determine insecticidal effects of the three different plant extract oils; thyme, bitter and neem against the $2^{\text {nd }}$ and $4^{\text {th }}$ larval instars of S. littoralis. Also, it extended to evaluate the most potent promising plant extracts on some biological and physiological aspects in the tested pest.

\section{MATERIALS AND METHODS}

\section{Tested pest}

A colony of cotton leaf worm, S. littoralis, was maintained in the laboratory for many generations without contamination with insecticides according to Ghoneim, (1985). The tests were carried out on the $2^{\text {nd }}$ and $4^{\text {th }}$ instars larvae.

\section{Plant extracts used:-}

The crude oils which used in this study was obtained from Recent Pesticides Company and formulated as $40 \%$ EC.

1-Thyme: Thymus vulgaris (Labiatae) (Family: Lamiaceae).

2-Bitter: Citrullus colocynthis (Handal) (Family: Cucurbitaceae)

3- Neem: Azadirachta indica (Family: Meliaceae),

\section{Toxicity tests}

Four concentrations of each extract were prepared in water ranged from $0.062 \%$ to $0.5 \%$ as required for the bioassay tests against the $2^{\text {nd }}$ and $4^{\text {th }}$ instars of S. littoralis. The castor bean leaves were dipped in each concentration of the plant extracts for 20 second and left to dry then five replicates of 10 larvae of each concentration were fed on the treated leaves for $48 \mathrm{hrs}$. The surviving larvae were transferred to clean cups and supplied daily with untreated leaves until pupation. For control, plant leaves were dipped in fresh water. Mortality was recorded daily after treatment and the $\mathrm{LC}_{50}{ }^{\mathrm{s}}$ were determined for each tested oil.

\section{Biological experiments:}

The effect of $\mathrm{LC}_{50}{ }^{\mathrm{s}}$ on some biological aspects of the treated instars and its subsequent developmental stages were studied on the $2^{\text {nd }}$ and $4^{\text {th }}$ instars larvae of $S$. littoralis which fed on castor bean leaves treated with $\mathrm{LC}_{50}$ 's of thyme, bitter and neem oils for $48 \mathrm{hrs}$. In control, leaves were treated with distilled water only. Larval and pupal duration, pupal weight, pupation $\%$, adult emergence $\%$, adult longevity, malformation of different stages and sex ratio, were recorded.

\section{Biochemical studies:}

All the biochemical analysis was carried out in Physiology Department, Plant Protection Research Institute.

\section{Tissue preparation:}

Total body tissue samples were collected from late $6^{\text {th }}$ larval instars treated as $4^{\text {th }}$ instars fed on treated leaves with $\mathrm{LC}_{50}$ values of the used compounds. Insect bodies of 
treated or untreated were homogenized in distilled water (one gm. insect bodies / 5 $\mathrm{ml}$ ) using a chilled glass teflon tissue grinder for $3 \mathrm{~min}$. Homogenates were centrifuged at 8000 r.p.m for $15 \mathrm{~min}$ at $-2^{\circ} \mathrm{C}$ in a refrigerated centrifuge. The supernatant used stored at $-5^{\circ} \mathrm{C}$ until the use (Max-2 week) for determination of some enzyme activities included chitinase, protease, AchE, $\alpha$ - and $\beta$ - non specific esterases.

Enzyme activity

Chitinase: Colloidal chitin was determined according to Bade and Stinson (1981).

Protease: was determined according to Tatchell et al., (1972)

Acetylcholine esterase (AchE): was determined according to Simpson et al. (1964) using acetylcholine bromide (AchBr) as substrate.

$\boldsymbol{\alpha}$ - and $\boldsymbol{\beta}$ - non specific esterases were determined according to Van Asperen (1962) method using $\alpha$ - naphthyl acetate or $\beta$ - naphthyl acetate as substrates, respectively.

\section{Statistical analysis:}

Mortality were recorded daily after treatment until the end of experiment and corrected according to Abbott (1925). Also, mortality values were analyzed by probit analysis (LPD line) to obtain $\mathrm{LC}_{50}$ and slope for each extract according to a method adopted by Finney (1971). LC $_{50}$ values, were computed and used for calculating the toxicity index (Sun, 1950) which was used for comparing the relative toxicity of insecticides used.

Sun's toxicity index $=\mathrm{LC}_{50}$ or $\mathrm{LC}_{90}$ of the most toxic compound/ $\mathrm{LC}_{50}$ or $\mathrm{LC}_{90}$ of the tested compounds $\mathrm{x} 100$.

Relative Potency $=\mathrm{LC}_{50}$ of the least toxic compound/ $\mathrm{LC}_{50}$ of the tested compounds Activity ratio=enzymatic activity of the tested strain/ enzymatic activity of the control.

\section{RESULTS AND DISSCUSSION}

\section{1-Toxicity tests:-}

Based on the $\mathrm{LC}_{50}$ values of the tested products, the present results indicated that all the tested insecticides have larvicidal activities against both $2^{\text {nd }}$ and $4^{\text {th }}$ instar larvae. As shown in Table (1), thyme oil proved to be the most toxic plant extraction to both $2^{\text {nd }}$ and $4^{\text {th }}$ instars larvae; the corresponding $\mathrm{LC}_{50}$ values were $0.078 \&$ $0.113 \%$, respectively followed by bitter, where the corresponding $\mathrm{LC}_{50}$ values were $0.116 \& 0.184 \%$, respectively and of neem these values were $0.153 \& 0.21 \%$, respectively. By comparison, the other two oils produced showed low activity recording toxicity index values of $67.24 \& 61.41$ and $50.98 \& 53.81$ for bitter and neem oils, respectively as effective as thyme on $2^{\text {nd }}$ and $4^{\text {th }}$ instars. The relative potency level can be used as a convenient method in comparing the degree of toxicity of the different compounds in this study. The potency levels of the tested insecticides are expressed as number of folds, at the required toxicity level, compared with the least efficient toxicant included in the evaluation in the study.

Concerning the relative potency levels based on the $\mathrm{LC}_{50}$ values as represented in Table (1), the larvacidal activity values of thyme and bitter oils were $1.96 \& 1.86$ and $1.32 \& 1.14$ times as toxic as larvacidal action of neem oil against the $2^{\text {nd }}$ and $4^{\text {th }}$ instars of S. littoralis, respectively. 
Table 1: Susceptibility of the $2^{\text {nd }}$ and $4^{\text {th }}$ instars larvae of the cotton leaf worm S. littoralis to three plant extract oils.

\begin{tabular}{|c|c|c|c|c|c|}
\hline \multirow{3}{*}{ Treatments } & \multicolumn{5}{|c|}{$2^{\text {nd }}$ instars } \\
\hline & \multirow[t]{2}{*}{$\mathrm{LC}_{50} \%$} & \multirow{2}{*}{$\begin{array}{l}\text { Slope } \\
\pm \text { S.E }\end{array}$} & 95\%Fiduciual limits & \multirow[t]{2}{*}{ Toxicity index } & \multirow{2}{*}{$\begin{array}{c}\text { Relative } \\
\text { potency } \\
\text { levels }\end{array}$} \\
\hline & & & lower-upper & & \\
\hline Thyme & 0.078 & $1.36 \pm 0.32$ & $0.038-0.111$ & 100 & 1.96 \\
\hline Bitter & 0.116 & $1.44 \pm 0.28$ & $0.076-0.155$ & 67.24 & 1.32 \\
\hline Neem & 0.153 & $0.782 \pm 0.29$ & $0.076-0.33$ & 50.98 & 1 \\
\hline \multirow{3}{*}{ Treatments } & \multicolumn{5}{|c|}{$4^{\text {th }}$ instars } \\
\hline & $\mathrm{LC}_{50} \%$ & $\begin{array}{l}\text { Slope } \\
+ \text { S.E }\end{array}$ & $\begin{array}{c}\text { 95\% Fiduciual } \\
\text { limits }\end{array}$ & Toxicity index & $\begin{array}{c}\text { Relative } \\
\text { potency levels }\end{array}$ \\
\hline & & & lower-upper & & \\
\hline Thyme & 0.113 & $1.055 \pm 0.27$ & $0.055-0.166$ & 100 & 1.86 \\
\hline Bitter & 0.184 & $1.653 \pm 0.31$ & $0.134-0.245$ & 61.41 & 1.14 \\
\hline Neem & 0.21 & $0.878 \pm 0.27$ & $0.122-0.387$ & 53.81 & 1 \\
\hline
\end{tabular}

According to the estimated $\mathrm{LC}_{50}$ values, the $2^{\text {nd }}$ instar larvae reflected higher level of susceptibility towards all the tested oil than the $4^{\text {th }}$ instars. These results are in harmony with Shabnum and Wagay (2011) who concluded that three of the essential oils, thyme (Thymus vulgaris) were highly toxic to the cutworms Agrotis ipsilon. Similary, Abd El-Mageed and Shalaby (2011) reported higher susceptibility of some new insecticides to the $2^{\text {nd }}$ instars than $4^{\text {th }}$ instars of $S$. littoralis and this may be contributed to the tolerance levels which were generally less than those of old ones.

Effect of the $\mathrm{LC}_{50}$ values of the tested products on larval duration, pupal duration and adult longevity.

The results of the larval duration starting from initial instars treated up to pupation recorded from the treated $2^{\text {nd }}$ and $4^{\text {th }}$ instar larvae with the $\mathrm{LC}_{50}$ 's values of the tested products are presented in (Table 2). The obtained results showed in significant decreased in case of pretreated $2^{\text {nd }}$ instars which ranged $11.0,10.8 \& 10.5$ days for thyme, bitter and neem, compared with 12.2 days for control. While there were significant prolongation in larval duration for the pretreated $4^{\text {th }}$ instars ranged between $10.48 \& 11.58$ days as compared with 8.25 days for control.

Table 2: Effect of $\mathrm{LC}_{50}$ values of three plant extract oils on larval duration, pupal duration and adult longevity of $2^{\text {nd }}$ and $4^{\text {th }}$ instar larvae of cotton leaf worm $S$. littoralis.

\begin{tabular}{|c|c|c|c|c|c|c|c|c|}
\hline \multirow{2}{*}{$\begin{array}{c}\text { Compoun } \\
\text { ds }\end{array}$} & \multicolumn{2}{|c|}{$\begin{array}{l}\text { Larval duration } \\
\text { (mean days } \pm \text { S.E) }\end{array}$} & \multicolumn{2}{|c|}{$\begin{array}{l}\text { Pupal duration } \\
\text { ( mean days } \pm \text { S.E) }\end{array}$} & \multicolumn{4}{|c|}{$\begin{array}{c}\text { Adult longevity(mean days } \pm \text { S.E) } \\
2^{\text {nd }} \\
4^{\text {th }}\end{array}$} \\
\hline & $2^{\text {nd }}$ & $4^{\text {th }}$ & $2^{\text {nd }}$ & $4^{\text {th }}$ & $\hat{0}$ & $q$ & $\hat{0}$ & q \\
\hline Thyme & $\begin{array}{c}11.0 \pm \\
0.58 \\
\end{array}$ & $\begin{array}{c}10.48 \pm \\
0.85^{\mathrm{a}}\end{array}$ & $\begin{array}{l}19.93 \pm \\
0.65^{\mathrm{a}}\end{array}$ & $\begin{array}{l}19.0 \pm \\
1.68^{\mathrm{a}} \\
\end{array}$ & $\begin{array}{c}4.33 \pm \\
1.2 \\
\end{array}$ & $\begin{array}{l}3.5 \pm \\
0.65\end{array}$ & $\begin{array}{c}4.0 \pm \\
0.58^{\mathrm{ab}} \\
\end{array}$ & $\begin{array}{l}3.25^{ \pm} \\
0.75^{\mathrm{b}}\end{array}$ \\
\hline Bitter & $\begin{array}{c}10.8 \pm \\
0.85 \\
\end{array}$ & $\begin{array}{c}10.79 \pm \\
0.65^{\mathrm{a}} \\
\end{array}$ & $19.5 \pm 2.1^{\mathrm{a}}$ & $\begin{array}{l}21.2 \pm \\
0.86^{\mathrm{a}} \\
\end{array}$ & $\begin{array}{c}3.67 \pm \\
0.67\end{array}$ & $\begin{array}{l}4.2 \pm \\
0.49\end{array}$ & $\begin{array}{c}2.8 \pm \\
0.37^{\mathrm{b}}\end{array}$ & $\begin{array}{l}3.25 \pm \\
0.25^{\mathrm{b}}\end{array}$ \\
\hline Neem & $\begin{array}{c}10.5 \pm \\
0.65 \\
\end{array}$ & $\begin{array}{c}11.58 \pm \\
0.44^{\mathrm{a}}\end{array}$ & $\begin{array}{c}18.6 \pm \\
1.029^{\mathrm{a}} \\
\end{array}$ & $\begin{array}{l}19.2 \pm \\
0.05^{\mathrm{a}} \\
\end{array}$ & $\begin{array}{c}3.75 \pm \\
0.48\end{array}$ & $\begin{array}{l}4.0 \pm \\
0.58 \\
\end{array}$ & $\begin{array}{c}2.67 \pm \\
0.06^{\mathrm{b}}\end{array}$ & $\begin{array}{c}3.33 \pm \\
0.012^{\mathrm{b}}\end{array}$ \\
\hline Con & $12.2 \pm 0.3$ & $\begin{array}{l}8.25 \pm \\
0.3^{\mathrm{b}}\end{array}$ & $\begin{array}{l}13.57 \pm \\
0.53^{\mathrm{b}}\end{array}$ & $\begin{array}{l}13.57 \pm \\
0.53^{\mathrm{b}}\end{array}$ & $\begin{array}{l}4.7 \pm \\
0.33\end{array}$ & $\begin{array}{l}5.5 \pm \\
1.21\end{array}$ & $\begin{array}{l}4.7 \pm \\
0.33^{\mathrm{a}}\end{array}$ & $\begin{array}{c}5.5 \pm \\
1.21^{\mathrm{a}}\end{array}$ \\
\hline F value & $1.376^{\mathrm{ns}}$ & $5.2^{*}$ & $27.744 * * *$ & $15.38 * * *$ & $0.32^{\mathrm{ns}}$ & $1.525^{\mathrm{ns}}$ & $4.476^{*}$ & $3.921 * *$ \\
\hline L.S.D $0_{0.05}$ & - & 2.1096 & 2.5754 & 2.4775 & & & 1.4381 & 1.7321 \\
\hline
\end{tabular}

All the tested oils showed highly significant prolongation in pupal duration in both $2^{\text {nd }}$ and $4^{\text {th }}$ instars. The most prolonged pupae resulted from thyme treatment on the $2^{\text {nd }}$ instars (19.93 days) followed by bitter and then neem $19.5 \& 18.6$ days, 
respectively. Whereas the $4^{\text {th }}$ instars showed highly significant prolongation reached its maximum by bitter 21.2 days followed by neem and thyme $19.2 \& 19.0$ days, respectively compare with 13.57 days for control. Both males and females moths longevity were reduced with all the tested oils specially the males which were more affected as a results of both pretreated $2^{\text {nd }}$ and $4^{\text {th }}$ instars to record $3.75 \& 2.67$ days and significant reduction of $3.67 \& 2.8$ days, by neem and bitter, respectively. While insignificant reduction was recorded on females longevity as a results of pretreated $2^{\text {nd }}$ instars but significant reduction for pretreated $4^{\text {th }}$ instars ranged $3.5 \& 4.2$ and $3.25 \&$ 3.33 days, respectively especially with thyme .

All treatments recorded significantly difference in all durations for both $2^{\text {nd }}$ and $4^{\text {th }}$ instars. The decrease in the larval, pupal and adults longevity here may reflect metamorphosis disruption these results are agreed with Hatem et al. (2008) they showed significantly prolonged larval and pupation periods with azadirachtin superior than Spinosad. Similarly Riba et al., (2003) azadirachtin (neem oil) has growth regulatory effect causing greatly extended instar lengths, delayed molts, mortality at ecdysis of N.viridula.

\section{2-Effect of $\mathrm{LC}_{50}$ values of three plant extract oils on pupation, pupal weight, adult emergence and sex ratio.}

The data presented in Table (3) showed highly significant reduction in pupal weight resulted from both $2^{\text {nd }}$ and $4^{\text {th }}$ instars treated with $\mathrm{LC}_{50}$ values of thyme, bitter and neem oils where ranged between $0.315 \& 0.32$ and $0.312 \& 0.346$ gm compared with $0.413 \mathrm{gm}$ of control.

Table 3: Effect of $\mathrm{LC}_{50}$ values of three plant extract oils on pupation, pupal weight, adult emergence and sex ratio of $2^{\text {nd }}$ and $4^{\text {th }}$ instar larvae of cotton leaf worm $S$. littoralis.

\begin{tabular}{|c|c|c|c|c|c|c|c|c|}
\hline \multirow{3}{*}{ Compounds } & \multirow{2}{*}{\multicolumn{2}{|c|}{ Pupation \% }} & \multirow{2}{*}{\multicolumn{2}{|c|}{ Pupal weight $(\mathrm{gm} \pm$ S.E) }} & \multirow{2}{*}{\multicolumn{2}{|c|}{$\begin{array}{c}\text { Adult } \\
\text { emergence \% }\end{array}$}} & \multicolumn{2}{|c|}{ Sex ratio } \\
\hline & & & & & & & & $4^{\text {th }}$ \\
\hline & $2^{\text {nd }}$ & $4^{\text {th }}$ & $2^{\text {nd }}$ & $4^{\text {th }}$ & $2^{\text {nd }}$ & $4^{\text {th }}$ & $\hat{0}+$ & ô \\
\hline Thyme & 36.51 & 46.77 & $0.315 \pm 0.01^{\mathrm{b}}$ & $0.334 \pm 0.01^{\mathrm{b}}$ & 23.81 & 17.74 & $1.5: 1$ & $1.75: 1$ \\
\hline Bitter & 42.19 & 40 & $0.32 \pm 0.012^{b}$ & $0.346 \pm 0.01^{b}$ & 20.31 & 25 & $1.17: 1$ & $2: 1$ \\
\hline Neem & 49.15 & 45.24 & $0.315 \pm 0.11^{b}$ & $0.312 \pm 0.02^{b}$ & 25.42 & 12.29 & $1.14: 1$ & $1: 1$ \\
\hline Control & 92 & 92.00 & $0.413 \pm 0.01^{\mathrm{a}}$ & $0.413 \pm 0.01^{\mathrm{a}}$ & 84 & 84 & 0.91: 1 & 0.91: 1 \\
\hline F value & -- & - & $33.6629 * * *$ & $20.7946 * * *$ & & & & \\
\hline L.S.D $\mathbf{D . 0 5}_{0 .}$ & ---- & - & 0.02986 & 0.0343 & & & & \\
\hline
\end{tabular}

The treated $2^{\text {nd }}$ instars with $\mathrm{LC}_{50}$ values of the plant oils markedly reduced metamorphosis to pupae to approximately by the third compared with control. Pupation percentage was the lowest $36.51 \%$ when the $2^{\text {nd }}$ instars treated with thyme and was $46.77 \%$ with the $4^{\text {th }}$ instars respectively, Pupation percentage was slightly higher $40 \%$ and $42.19 \%$ by bitter against both $2^{\text {nd }}$ and $4^{\text {th }}$ instars and reached to $45.24 \%$ and $49.15 \%$ for neem in case of treated $2^{\text {nd }}$ and $4^{\text {th }}$ instars, respectively. Table (3)showed that the percentages of adult emergence were reduced to 12.29 and $17.74 \%$ for neem and thyme on pretreated $4^{\text {th }}$ instars while bitter having the highest reduction in the adult emergence percentages $(20.31 \%)$ in case of pretreated $2^{\text {nd }}$ instars compared to $84 \%$ for control. Also, all the tested oil generally affected on the sex ratio by producing of males more than females (about 2 folds), the most effective oil was thyme which affected on both pretreated $2^{\text {nd }}$ and $4^{\text {th }}$ instars $(1.5: 1)$ and $(1.75: 1)$, respectively followed by bitter $(2: 1)$ on the pretreated $4^{\text {th }}$ instars compare with control $(0.91: 1)$. i. e. high proportion of males production. This is interesting to decrease in population build up. These results are occurance with these found by Hummelbrunner and Isman (2001) they recorded that thymol prolonged both larval 
and pupal periods as well as reduced the pupal weight, and significantly more male adults were produced than females and pupation (35\%) of S. litura was by thymol.

The failure in adult emergence was observed by Bakr et al., (2012) when tested three newly insecticides against larvae of $S$. littoralis, also, the neem oil reduced the pupation to $52.33 \%$ compared with control $(69.67 \%)$.

\section{3-Effect of $\mathrm{LC}_{50}$ values of three plant extract oils on deformations of larvae, pupae and adult.}

Results illustrated in Table (4) showed that the tested plant extract oils caused deformations with various degree for larvae, pupae and adults resulted from either $2^{\text {nd }}$ or $4^{\text {th }}$ instar larvae of $S$. littoralis fed on castor oil bean leaves treated with the $\mathrm{LC}_{50}$ values of each oil. Deformations and malformations were recorded based on the external morphology.

The highest percentage of deformation exist in larval - pupa intermediate and recorded $(28.57 \& 14.52 \%)$ for thyme in pretreated $2^{\text {nd }}$ and $4^{\text {th }}$ instars, respectively followed by neem in case of $2^{\text {nd }}$ instars treatment $(27.12 \%)$ and recorded the lowest value in pretreated $4^{\text {th }}$ instars with neem $(2.38 \%)$ as compared with control which didn't show any larval deformations.

Table 4: Effect of $\mathrm{LC}_{50}$ values of three plant extract oils on deformations of larvae, pupae and adult malformations of $2^{\text {nd }}$ and $4^{\text {th }}$ instar larvae of cotton leaf worm S. littoralis.

\begin{tabular}{|c|c|c|c|c|c|c|c|c|c|c|c|c|c|c|}
\hline \multirow{2}{*}{ Compounds } & \multicolumn{2}{|c|}{ Larva- pupa\% } & \multicolumn{2}{|c|}{$\underset{\%}{\text { m.p } \underset{\%}{\&} . a d}$} & \multicolumn{2}{|c|}{$\begin{array}{c}\text { Dead pupae } \\
\%\end{array}$} & \multicolumn{2}{|c|}{$\begin{array}{c}\text { Total deformation } \\
\%\end{array}$} & \multicolumn{4}{|c|}{$\begin{array}{c}\text { Adult malformation } \\
\%\end{array}$} & \multicolumn{2}{|c|}{$\begin{array}{c}\text { Total } \\
\text { malformation }\end{array}$} \\
\hline & $2^{\text {nd }}$ & $4^{\text {th }}$ & $2^{\text {nd }}$ & $4^{\text {th }}$ & $2^{\text {nd }}$ & $4^{\text {th }}$ & $2^{\text {nd }}$ & $4^{\text {th }}$ & & q & & 우 & $2^{\text {nd }}$ & $4^{\text {th }}$ \\
\hline Thyme & 28.57 & 14.52 & 9.52 & 20.97 & 3.17 & 8.06 & 41.269 & 43.55 & 7.94 & 7.94 & 9.68 & 4.84 & 57.14 & 58.06 \\
\hline Bitter & 12.5 & 6.67 & 7.81 & 6.67 & 14.06 & 8.33 & 34.37 & 21.67 & 9.38 & 6.25 & 15 & 6.67 & 50 & 43.34 \\
\hline Neem & 27.12 & 2.38 & 13.56 & 14.29 & 8.47 & 16.67 & 49.15 & 33.34 & 10.17 & 6.78 & 2.38 & 4.76 & 66.1 & 40.48 \\
\hline Control & - & - & 2 & 2 & 4 & 4 & 6 & 6 & - & 2 & - & 2 & 8 & 8 \\
\hline
\end{tabular}

The pupal deformations and pupa- adult intermediate manifested in Table (4)showed that thyme gave the highest deformation $(20.97 \%)$ as pretreated $4^{\text {th }}$ instars followed by neem treatment to the $2^{\text {nd }}$ and $4^{\text {th }}$ instars $(13.56 \& 14.29 \%)$, respectively. Some pupae failed to emerge to moths and dead during pupal stage $(16.67 \%)$ in pretreated $4^{\text {th }}$ instar with neem followed by bitter $(14.06 \%)$ in pretreated $2^{\text {nd }}$ instar compared with control (4\%).

The total deformation during larval and pupal stages were recorded in Table (4). Neem was the most effective on by causing highest total deformation $(49.15 \%)$ in pretreated $4^{\text {th }}$ instars whereas thyme caused highest deformation for both pretreated $2^{\text {nd }}$ and $4^{\text {th }}$ instars $(41.27 \& 43.55 \%)$, respectively.

All tested plant oils caused various degrees of adult malformations when $S$. littoralis treated in the $2^{\text {nd }}$ and $4^{\text {th }}$ instars and the adult males showed higher effect than females. Pretreated $4^{\text {th }}$ instars with bitter recorded the highest malformation $(15 \%)$ followed by neem $(10.17 \%)$ on the pretreated $2^{\text {nd }}$ instars while the lowest value of males malformation was by neem on the pretreated $4^{\text {th }}$ instars. The females moth recoded malformation in range of $(4.76 \& 7.94 \%)$ for neem and bitter for $4^{\text {th }}$ and $2^{\text {nd }}$ instars, respectively.

The total malformation during generation recorded its maximum value with neem treatment $(66.1 \%)$ with $2^{\text {nd }}$ instars then thyme had higher effect in both $4^{\text {th }}$ and $2^{\text {nd }}$ instars $(58.06 \& 57.17 \%)$, while bitter recorded $(50 \& 43.34 \%)$, respectively compared with (8\%) for control.

Several abnormality, possibly related to defective molting were observed as affected by plant extract oils. Larvae had problem in discarding the old cuticle or precocious molt lead to production of abnormal chitin deposition. Our results agreed 
with (Riba et al., (2003) they recorded that azadirachtin exhibiting classic symptoms of abnormal molts, pupa-adult intermediate and growth inhibition, Increasing doses of azadirachtin in larval stages resulted several abnormalities and deformities on $S$. exigua and could be a result from the following kinds of growth disruption, which some of them involved negatively in vital activities such as feeding, walking or flying (Elumalai et al., 2010; Zarate et al., 2011 and Korrat ,et al., 2012) whose explained that the metamorphosis of the larvae of $S$. littoralis treated with three newly insecticides were failed to pupate, deformed prepupae and pupae can't complete the molting process and died. As well, larvae fed on high dose of two IGRs reduced phosphorous liberation for energy metabolism, decreased rate of metabolism, as well as decreased rate of transport of metabolites so, the dead larvae showed the symptom of improper metamorphosis from one instar to another instar.

\section{Enzyme activity:}

\section{1-Chitinase activity:}

Table (5) demonstrated the effect of thyme, bitter and neem oils on chitinase and protease activities in total homogenate of $6^{\text {th }}$ instar larvae of $S$. littoralis resulted from the treated when treated as $4^{\text {th }}$ instar for $48 \mathrm{hrs}$ with $\mathrm{LC}_{50}$ values of the three tested oils. The tested oils caused highly significant stimulation in chitinase activity and the most effective ones was thyme with remarkably significant stimulation $(+39.27 \%)$ followed by bitter $(12.74 \%)$ and neem $(5.32 \%)$ compared with control. Depending on the activity ratios, the tested oils enhanced chitinase by $1.05,1.39$ and 1.13 folds (Table, 5) when treated by thyme, bitter and neem oils, respectively than control. Our results in agreement with these finding by Abd El-Mageed and Shalaby (2011) they found that chitinase activity was increased when $S$. littoralis larvae was treated with different insecticides. In addition, the increase in chitinase activity could be attributed to the secondary effect of chitin synthesis inhibitor, or may be a secondary effect for the reduced activity of $\beta$-ecdysone metabolizing enzymes, followed by $\beta$-ecdysone accumulation which result in hyperchitinase activity. (Yu and Terriere, 1977).

Table 5: Changes in chitinase and protease activities of $6^{\text {th }}$ instar larvae when treated in the $4^{\text {th }}$ instar with $\mathrm{LC}_{50}$ values of three plant extract oils.

\begin{tabular}{|c|c|c|c|c|c|c|}
\hline Treatment & $\begin{array}{c}\text { Chitinase } \\
* \text { Mean } \pm \text { SE }\end{array}$ & $\begin{array}{c}\text { Change } \\
\%\end{array}$ & $\begin{array}{c}\text { Activity } \\
\text { ratio }\end{array}$ & $\begin{array}{c}\text { Protease } \\
* \text { Mean } \pm \text { SE }\end{array}$ & $\begin{array}{c}\text { Change } \\
\%\end{array}$ & $\begin{array}{c}\text { Activity } \\
\text { ratio }\end{array}$ \\
\hline Thyme & $700 \pm 5.78^{\mathrm{a}}$ & 5.32 & 1.05 & $42.93+1.36^{\mathrm{c}}$ & -37.9 & 0.62 \\
\hline Bitter & $925.67 \pm 39.4^{b}$ & 39.27 & 1.39 & $26.9 \pm 1.23^{\mathrm{d}}$ & -61.1 & 0.39 \\
\hline Neem & $749.33+18.8^{b}$ & 12.74 & 1.13 & $82.8+2.61^{\mathrm{a}}$ & 19.77 & 1.198 \\
\hline Control & $664.67 \pm 24.6^{b}$ & & 1 & $69.13 \pm 2.02^{b}$ & & 1 \\
\hline F value & \multicolumn{3}{|c|}{$26.162 * * *$} & \multicolumn{3}{|c|}{$178.533 * * *$} \\
\hline L.S.D ${ }_{0.05}$ & \multicolumn{3}{|c|}{82.201} & \multicolumn{3}{|c|}{6.1537} \\
\hline
\end{tabular}

*Mean with the same letter are not significant different.

*Mean: $\mu$ g NAGA/min/g.b.wt , SE: Stander error

\section{2-Protease activity:}

Results represented in Table (5) revealed that highly significant effect of the tested products on the protease activity which fluctuated between increase and decrease as a result of treatment. It was obvious that both treatments with bitter and thyme exhibited remarkable inhibition in protease activity which was significantly high $-61.1 \%$ in bitter treatment and moderate $-37.9 \%$ in thyme treatment. While high significant stimulation was recorded $19.77 \%$ by neem treatment compare with control.

The activity ratios of protease based on control proved less value by 0.62 and 0.39 time for thyme and bitter, respectively but neem was enhanced by 1.196 times 
than control. Our result are agreed with El- Sheikh et al., (2009) and Abdel-Aal and El- Sheikh(2012) who recorded significant increase in protease of S. littoralis larvae with treated with spinosad, tebufenozide, Diple $2 \mathrm{x}$ and its mixture with two insecticides and change in the activity of chitinase .

3-Non specific esterases( $\alpha$ - esterases and $\beta$ - esterases)activity:

Data shown in Table (6) illustrated that all treatments caused remarkable stimulation in $\alpha$--esterase activity which was significantly high 61.16 and $60.75 \%$ in bitter and neem treatment and low $26.86 \%$ in thyme treatment compared with control.

The activity ratio, of $\alpha$ - esterase was enhanced by $1.27,1.61$ and 1.61 times as a result of treated by thyme, bitter and neem oils than control, respectively. Similarly data in the same Table (6) revealed high significant stimulation in all treatments in $\beta$ esterases activity and the most effective was bitter (120.7\%) followed by neem (97.27\%), while thyme showed the least stimulation (52.14\%). In the same trend the activity ratio, of $\beta$ - esterase as represented in Table (6), was enhanced by 1.52, 2.21 and 1.97 times as a result of treated by thyme, bitter and neem oils than control, respectively.

Table 6: changes in $\alpha$ - and $\beta$ - esterase activities of $6^{\text {th }}$ instar larvae when treated in the $4^{\text {th }}$ instar with $\mathrm{LC}_{50}$ values of three plant extract oils.

\begin{tabular}{|c|c|c|c|c|c|c|}
\hline treatment & $\begin{array}{l}\alpha \text { - esterase } \\
* \text { Mean } \pm \text { SE }\end{array}$ & $\begin{array}{c}\text { Change } \\
\%\end{array}$ & $\begin{array}{c}\text { Activity } \\
\text { ratio }\end{array}$ & $\begin{array}{l}\boldsymbol{\beta} \text { - esterase } \\
* \text { Mean } \pm \text { SE }\end{array}$ & $\begin{array}{c}\text { Change } \\
\%\end{array}$ & $\begin{array}{c}\text { Activity } \\
\text { ratio }\end{array}$ \\
\hline Thyme & $204.67 \pm 3.7^{b}$ & 26.86 & 1.27 & $166.33+2.85^{\mathrm{c}}$ & 52.14 & 1.52 \\
\hline Bitter & $260 \pm 8.08^{\mathrm{a}}$ & 61.16 & 1.61 & $241.33+4.37^{\mathrm{a}}$ & 120.7 & 2.21 \\
\hline Neem & $259.33+5.21^{\mathrm{a}}$ & 60.75 & 1.61 & $215.67+4.9^{\mathrm{b}}$ & 97.27 & 1.97 \\
\hline Control & $161.33+4.49^{\mathrm{c}}$ & & 1 & $109.33+4.7^{\mathrm{d}}$ & & 1 \\
\hline F value & \multicolumn{3}{|c|}{$71.946 * * *$} & \multicolumn{3}{|c|}{$184.708 * * *$} \\
\hline L.S.D $D_{0.05}$ & \multicolumn{3}{|c|}{18.328} & \multicolumn{3}{|c|}{13.974} \\
\hline
\end{tabular}

*Mean with the same letter are not significant different.

*Mean: Ug a naphthol/min/g.b.wt.

SE: Stander error.

Our results are agreed with El- Sheikh, et al., (2009) who found that the tested compounds caused a disturbance in the activities of enzymes either with increase $\alpha$ and $\beta$ - esterase activities or with decrease. The non significant alternation in esterases under this study may be due to the absence of affinity between the chemical structure of plant oils and the tissue esterases but such phenomenon my be able to change with the metabolite of oils.

Acetylcholine esterase (AchE) activity:

The general fluctuation in the activity of the studied enzymes $(\alpha-, \beta$-esterases and AchE) in the present work may indicate that general esterases are involved in the detoxification process of the tested oils. Highly significant inhibition in AchE was recorded as a results of treatment with neem and thyme oils by (-56.5 and 34.86\%), respectively as represented in Table (7). It was of interest to note that bitter exhibited non significant stimulation of AchE (6.56\%) compared with control and significant with neem and thyme.

According to activity ratios, of AchE represented in Table (7), the obtained values -56.5 and -34.86 times less for neem and thyme treated, while +6.54 times more for bitter treatment compared with the control. AchE has a key role in neurotransmitter by hydrolyzing the neurotransmitter achetylcholine in cholinergic synapses of the nervous system and is the target site of several neurotoxic insecticides. 
Our results are agreed with that recorded by Abd-el-Aziz and El-Gohary(2013) who mentained that all treated insecticides inhibited acetylcholine esterase in the $4^{\text {th }}$ instar larvae of S. littoralis. El- Sheikh, et al., (2009) found the change of response to spinosad could be associated with the decrease in AchE activity.

Table 7: Changes in AchE activities of $6^{\text {th }}$ instar larvae when treated in the $4^{\text {th }}$ instar with $\mathrm{LC}_{50}$ values of Thyme, Bitter and Neem oils.

\begin{tabular}{|c|c|c|c|}
\hline Treatment & $\begin{array}{c}\text { AchE } \\
{ }^{*} \text { Mean } \pm \text { SE }\end{array}$ & Change \% & Activity ratio \\
\hline Thyme & $26.7+1.21^{\mathrm{b}}$ & -34.86 & 0.65 \\
\hline Bitter & $43.67+1.26^{\mathrm{a}}$ & +6.54 & 1.065 \\
\hline Neem & $17.83+0.83^{\mathrm{c}}$ & -56.5 & 0.43 \\
\hline control & $40.99+1.13^{\mathrm{a}}$ & & 1 \\
\hline F value & \multicolumn{3}{|c|}{$120.365^{* * *}$} \\
\hline L.S.D & $\mathbf{3 . 6 2 5}$ \\
\hline
\end{tabular}

This activity is apparently strongest during pupation; pupae were very susceptible after larval exposure (SenthilNathan, et al., 2005). The inhibitory effects of the extracted lectin on digestive $\alpha$-amylase of E. ceratoniae larvae. Proteins have been discovered and characterized, including lectins, ribosome - inactivating proteins, and protease and $\alpha$-amylase inhibitors, which have shown insecticidal effects on different insect pests Ramzi and Sahragard (2013). Elumalai et al., (2010) reported that neem oil showed significant insecticidal activity. It may due to reduction in the total protein content which is a major component for the metamorphosis of the larval instars, Our data support this hypothesis decreased levels of digestive enzyme may be due to the direct effect of botanical oil and enzyme regulation. Neem derivatives may interfere with the production of certain types of proteins.It is evident that exposure to botanical insecticides (Neem oil) in larval diet has significant effects on activities of several enzymes found in the late instar larvae and adult $S$. litura.

In addition, BiF, et al., (2008) stated that different commercial neem formulations probably have several modes of action. Primary of which is an interference with the neuroendocrine system in insects which controls the synthesis of ecdysone and juvenile hormone, and others are a more direct role in the inhibition of molting, the antifeedant and growth regulating effects. Other secondary effects was repellency, loss of flying ability and disrupting sexual communication (Jacobson, 1989) The reason behind deformities and malformations may be a result of changes in, chitinase ecdysis is initiated by apolysis, the process that separates epidermal cells from the old cuticle by molting fluid secretion and ecdysal membrane formation. Molting fluid contains protease and chitinase enzymes that digest the main constituents of the old endocuticle. Thus, the disruption in chitinase enzymes postulated the reason of deformations that agree with Nasr et al., (2010). The results obtained here consider promising for controlling S. littoralis. Sublethal effects of plant extracts may be of great importance in regulating population of a target pest by affecting physiological process. 48 hours feeding period was enough to promote morphological abnormalities, feeding suppression, inhibiting molting, preventing the formation of new integument and mortality of this pest. This suggests that these pests would complete fewer generations, multiply less quickly and would remain exposed to natural enemies for a longer period. This would supply natural control. High proportion of male's production interesting to decrease in population build up. These factors will cause less damage and will help increase crop yield. It can be concluded from the present study that larvicidal and growth inhibitory activity by the plant oil compounds could be 
beneficial as possible control of the S. littoralis. This is true specifically of thymol which has shown potential in both larval and adult.

\section{REFERENCES}

Abbott, M. S. (1925). A method of computing the effectiveness of an insecticide. J. Econ. Entomol., 18: 265-267.

Abdel-Aal, E. Aziza and El- Sheikh, T. A. (2012). Efficiency of Diple 2x (Bacillus thuringiensis var. kurstaki) alone and its mixture with two insecticides against the Egyptian cotton leaf worm Spodoptera littoralis (Lepidoptera: Noctuidae). Egyp. Acad. J. Biolog. Sci., (F-Toxicology and Pest control), 4(1): 61-68.

bd-El-Aziz, S. Hanan and El-Gohary, E. E. El-Gohary (2013):Biochemical studies of three novel insecticides in cotton leafworm Spodoptera. littoralis (Bosid.).Bull. Ent. Soc.,Egypt, Econ.Ser., (Received, Feb, 2013).

Abd El-Mageed A. E. M and Shalaby S. E. M. (2011).Toxicity and biochemical impacts of some new insecticide mixtures on cotton leafworm Spodoptera littoralis (Boisd.). Plant Protect Sci., 47(4):166-175.

Bade,M. L. and Stinson,A.(1981). Biochemistry and insect differentiation. A system for studying the mechanism of chitinase activity in vitro. Archs. Biochem. Biophy., 208.213-221.

Bakkali, F, Averbeck, S., Averbeck, D. and Idaomar, M. (2008). Biological effects of essential oils-A review. Food and chemical toxicology, 46: 446-475.

Bakr R.F.A, Hassan H.A, Abd El-Bar M.M, Nawwar G.A, Elbanna H.M. (2012). Toxicological and molecular studies of newly compounds extracted from wastes against cotton leaf worm Spodoptera littoralis. Egypt. Acad .J. Biolog. Sci. (A-Entomology ), 5(2):65-80.

Bi,F., Xiong L., Wang Q. and Huang R. (2008). Insecticidal activities of 15 insect growth regulators on Culex pipiens pallens. Pesti. Sci. Administr., 29: 25-27.

El- Sheikh, T. A., Abdel-Aal, E. Aziza and Farag, A.M. (2009). Effect of Spinosad and Tebufenozide on some biological, biochemical and immunological parameters of cotton leafworm, Spodoptera littoralis (Boisd.). Egypt. J. Agric. Res., 87 (2): 73-90.

Elumalai, K., Krishnappa, K., Anandan, A., Govindarajan M. and Mathivanan, T. (2010). Antifeedant activity of medicinal plant essential oils against Spodoptera litura (lepidoptera: noctuidae). International Journal of Recent Scientific Research, 2:062-068.

Finney, D. J. (1971). Probit Analysis. $3^{\text {rd }}$ ed., Cambridge Univ. Press, London: 318 p.

Ghoneim, K. S. (1985). Physiological studies on endocrine and reproductive system of the cotton leafworm, Spodoptera littoralis (Boisd) (Lepidoptera: Noctuidae). Ph.D. Thesis, Al-Azhar Univ., Cairo.

Hatem, A. E., Salwa, S. Abdel-Samad, M. and Abul -Fadl, H. A. A. (2008). Lethal effects of Spinosad and Azadirachtin on the cotton leafworm Spodoptera littoralis (Boisd.) (Lepidoptera: Noctuidae). Ann Agric Sci., 53(1): 273- 282.

Hummelbrunner L.A., Isman M.B. (2001). Acute, sublethal, antifeedant and synergistic effects of monoterpenopid essential oil compounds on the tobacco cutworm, Spodoptera litura (Lep., Noctuidae). J. Agric. Food Chem., 49:715-720. 
Jacobson, M. (1989). Botanical pesticides, past, present and future. In: Arnason J. T., Philogene, B. J. R., Morand, P.(Eds.),Insecticides of plant origin. American Chemical Society, Washington DC, pp. 1-10.

Khawas M. A. M., Abd El-Gawad H. A. S. (2002). The efficiency of two plant extracts (Fenugreek and Lupine) and commercial biofungicide (Biofly) on the cotton leafworm, Spodoptera littoralis (Boisd) (Lepidoptera : Noctuidae) larvae as a new approach of control. J. Egypt. Ger. Soc. Zool., 37: 39-57.

Korrat E. E. E., Abdel-Monem A. E., Helalia A. A. R, Khalifa H. M. S. (2012). Toxicological study of some conventional and nonconventional insecticides and their mixtures against cotton leafworm, Spodoptera littoralis (Boisd.) (Lepidoptera: Noctuidae). Ann Agric Sci., Crop Protection, 30: 645-650.

Nasr H. M., Badawy M. E. and Rabea E. I. (2010). Toxicity and biochemical study of two insect growth regulators, buprofezin and pyriproxyfen, on cotton leafworm Spodoptera littoralis. Pest. Bioch. and Physio., 98 198-205.

Ramzi, S. and Sahragard, A. (2013). A lectin extracted from Citrullus colocynthis L. (Cucurbitaceae) inhibits digestive -amylase of Ectomyelois ceratoniae Zeller (Lepidoptera: Pyralidae).J. Ent. and Acaro. Res., 45: 20.

Riba M., Marh, J. and Sans, A. (2003). Influence of azadirachtin on development and reproduction of Nezara viridula L. (Het., Pentatomidae). J. Appl. Entomol., 127: 37- 41.

Senthilnathan, S., KalaivanI K., Murugan, K. and Chung, P.G. (2005). The toxicity and physiological effect of neem limonoids on Cnaphalocrocis medinalis (Guenée) the rice leaf older, Pest. Biochem. Physiol., 81: 113-122.

Shabnum S. and Wagay, M. G. (2011). Essential oil Composition of Thymus Vulgaris L. and their Uses. J. Res.\& Dev. Vol.11 ISSN 0972-5407

Simpson, D. R., Bull, L. D., Lidquist, A.D. (1964).Asemi microtechnique for estimation of cholinesterase activity in boll weevil. Ann. Ent. Soc. Amer.57 (3): $367-371$.

Sun, Y.P. (1950). Toxicity index, an improved method of comparing the relative toxicity of insecticides, J. Econ. Ent., 43: 45-53.

Tatchell, R.G., S. S. Araman and F.N. Boctor (1972). Biochemical and physiological studies of certain Ticks (Ixodoidae). Z. parasiting E. N. K.,39:345-350.

Van asperen, K. (1962). A study of house fly esterase by means of sensitive colorimetric method. J. Insect Physiol., 8: 410-416. Yu, S. J. and L. C. Terriere, E. (1977). Ecdysin metabolism by soluble enzymes from three species of Diptera and its inhibition by the insect growth regulatar TH-6040, Pestic. Biochem. Physiol., 7: 48-55.

Zarate, N., Díaz O., Martínez, A. M., Figueroa, J. I., Schneider, M.I., Smagghe G., Viñuela, E., Budia, F. and Pineda, S. (2011). Lethal and sublethal effects of methoxyfenozide on the development, survival and reproduction on of the fall armyworm, Spodoptera frugiperda (J. E. Smith) (Lepidoptera: Noctuidae). Neotrop Entomol, 40(1):129-37. 


\section{ARABIC SUMMARY}

\section{تأثير بعض الزيوت النباتية علي بعض النظم البيولوجية والبيوكيميائية فى دودة ورق القطن}

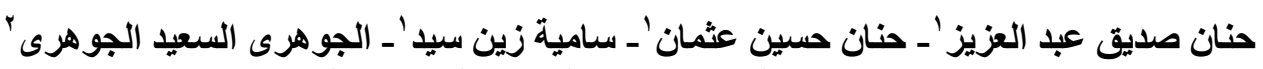

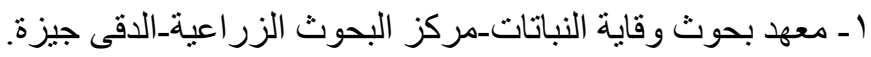

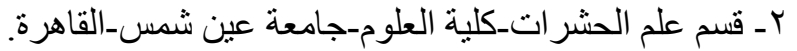

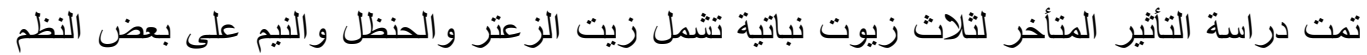

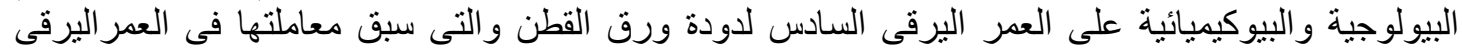

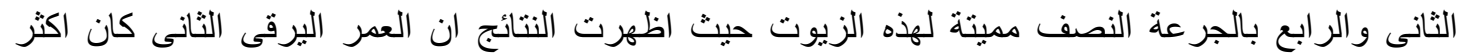

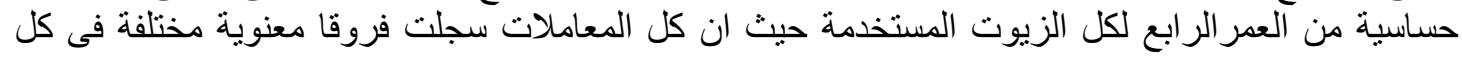

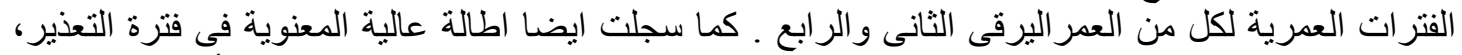

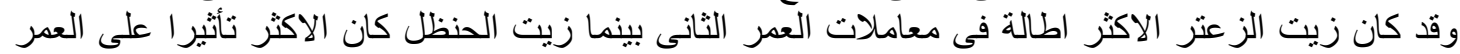

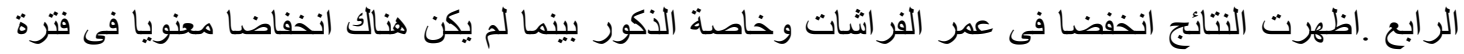

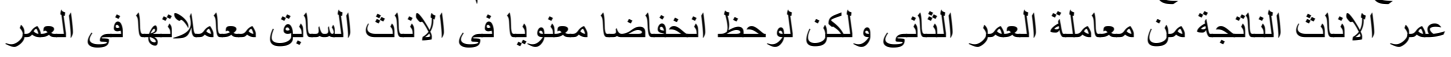

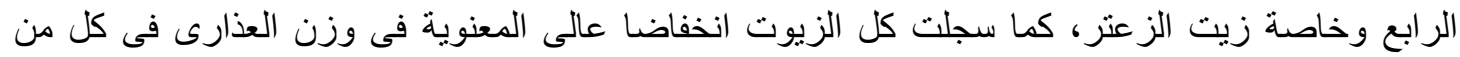

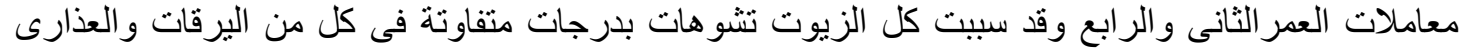

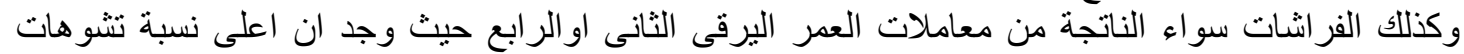

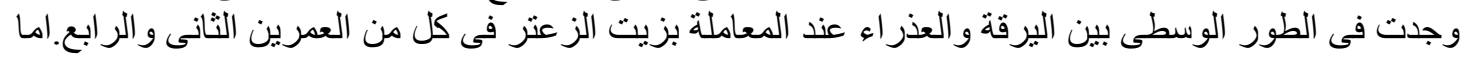

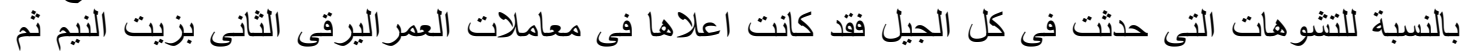

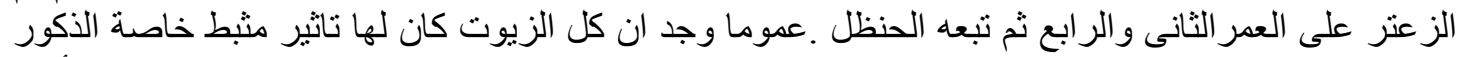

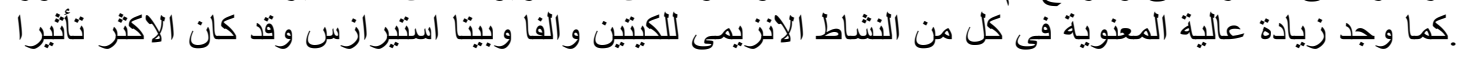

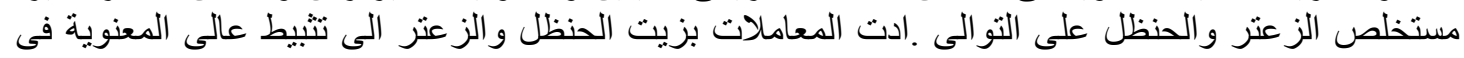

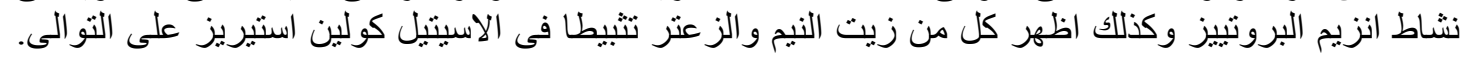

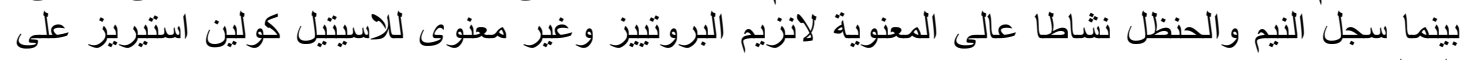

